\title{
Changes in luminal plasma and disappearance of spermatozoa from the ligated cauda epididymidis of the androgen-deficient rabbit
}

\author{
R. Jones and H. M. Dott \\ Agricultural Research Council Institute of Animal Physiology, Animal Research Station, \\ 307 Huntingdon Road, Cambridge CB3 OJQ, U.K.
}

\begin{abstract}
Summary. By 3 weeks after castration the majority of spermatozoa in the ligated cauda epididymidis were dead and decapitated and there was a $46 \%$ reduction in the total number of spermatozoa. By 5 weeks after castration $>99 \%$ of spermatozoa had disappeared. Electrophoresis of cauda epididymal plasma (CEP) on polyacrylamide gels revealed that after castration the protein composition of CEP changed from a pattern specific to the epididymis to one similar to blood serum. These changes in the luminal content could be prevented by administering testosterone. When spermatozoa from the cauda epididymidis were diluted in CEP from normal rabbits they remained motile for several hours at room temperature. Dilution in CEP from 3- or 5-week castrated animals stimulated vigorous forward motility but this declined to very low levels after $40 \mathrm{~min}$. The evidence indicates that dead spermatozoa can be removed from the epididymis after castration by mechanisms not involving granuloma formation.
\end{abstract}

\section{Introduction}

The fate of unejaculated spermatozoa in the epididymis has long been a controversial issue. Reports of spermiophagy by epithelial cells in the epididymis and vas deferens (Phadke, 1964; Roussel, Stallcup \& Austin, 1967; Crabo, Gustafsson, Nicander \& Rao, 1971; Tingari \& Lake, 1972; Hoffer, Hamilton \& Fawcett, 1975; Cooper \& Hamilton, 1977; Sinowatz, Wrobel, Sinowatz \& Kluger, 1979), discrepancies between sperm production and ejaculation rates (Amann \& Almquist, 1962; Koefoed-Johnson, 1964) and the presence of nucleolytic enzymes in epididymal secretions (Mann, 1964; Waldschmidt, Karg \& Kinzler, 1964; Mennella \& Jones, 1977) have tempted speculations that effete and dead spermatozoa are absorbed, so that only normal fertile cells are ejacuated (reviewed by Bedford, 1975). However attractive this hypothesis may be contemporary experimental evidence does not support it (e.g. see Amann, Kavanaugh, Griel \& Voglmayr, 1974), and it can be stated that, in the endocrinologically normal non-seasonal mammal, absorption and dissolution of spermatozoa in the epididymis is an unusual occurrence, and, if present at all, takes place to a very limited extent and is probably associated with a pathological condition.

It is also generally agreed that the epididymis involutes rapidly after castration and that 2-3 weeks after removing the testes few spermatozoa remain. Most of these spermatozoa simply pass down the vas deferens and are voided to the exterior in the urine. A comparable situation is found in the epididymis of seasonally breeding mammals as their testes regress at the end of their annual reproductive cycle (Millar, 1972; Lincoln, 1974). 
However, when ligatures are placed experimentally on the vas deferens and corpus epididymidis, spermatozoa are effectively retained within the cauda epididymidis and it is their fate under these conditions that is the subject of current debate. Lubicz-Nawrocki (1974) and Jones \& Glover (1975) reported a rapid decline in the number of spermatozoa in the ligated cauda epididymidis following removal of the testes but there was no change for at least 5 weeks if testosterone was administered. Recently, Temple-Smith \& Bedford (1978) repeated these experiments in hamsters and rabbits but could not find a significant reduction in sperm numbers after castration. They concluded that rupture of the duct followed by extravasation of spermatozoa into a granuloma was responsible for the loss of spermatozoa reported by earlier workers, and that "a state of androgen deficiency does not elicit special mechanisms for intraluminal sperm disposal". Since this was in direct contrast to the observations of Jones \& Glover (1975) we have repeated our original experiments paying special attention to sperm numbers and the occurrence of granulomata. We have also examined the effects of castration on the protein composition of the luminal plasma and investigated the motility of spermatozoa diluted in epididymal plasma from normal and castrated animals.

\section{Materials and Methods}

\section{Castration and ligation experiments}

Experiments were designed so that each animal served as its own control. Fifteen $1-2 \frac{1}{2}$-yearold New Zealand White rabbits were assigned equally to Groups I, II and III. Each rabbit was anaesthetized with an intravenous injection of pentobarbitone sodium (Nembutal: Abbott Laboratories, Kent, U.K.) and the left testis + epididymis were removed (control epididymis). The epididymis was carefully separated from the testis and ligatures were placed round the middle of the corpus epididymidis and the vas deferens (Plate 1). A 25-gauge hypodermic needle threaded onto a polypropylene cannula (i.d. $0.25 \mathrm{~mm}$; o.d. $0.5 \mathrm{~mm}$; ESCO Rubber Co. Ltd, Teddington, Middlesex, U.K.) was inserted into the vas deferens proximal to the ligature, and 25 $\mu \mathrm{l}$ of the luminal contents were withdrawn. The puncture site was resealed by squeezing with an artery forceps and the epididymis was stored at $-30^{\circ} \mathrm{C}$. The right testis was also removed but the epididymis (experimental epididymis) was replaced in the scrotum after ligation of the corpus epididymidis and vas deferens as described above. Care was taken to avoid undue disturbance to the blood supply and to preserve asepsis during surgery. Animals in Groups I and II were left for 3 and 5 weeks respectively and then killed with an overdose of pentobarbitone sodium. Group III rabbits received $500 \mu \mathrm{g}$ testosterone propionate/day (dissolved in $0.2 \mathrm{ml}$ arachis oil), beginning immediately after surgery and continued until autopsy at 5 weeks. The epididymis was then removed from the scrotum, the position of the ligatures was identified, and $25 \mu \mathrm{l}$ of the luminal contents were collected from the vas deferens as described for the control epididymis. Approximately $5 \mu \mathrm{l}$ luminal contents from the control and experimental epididymides were

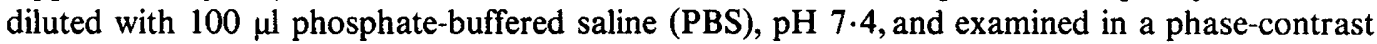
microscope fitted with a warm stage set at $30^{\circ} \mathrm{C}$ for determination of the percentage of motile spermatozoa. The remaining spermatozoa were smeared on clean glass slides and stained with nigrosin-eosin (Dott \& Foster, 1975) or haematoxylin and eosin. The percentages of live/dead and tailless spermatozoa were recorded from counts of 300 cells.

\section{Estimation of total sperm numbers in the cauda epididymidis}

For counting of the total number of spermatozoa, each cauda epididymal preparation was snap frozen on solid $\mathrm{CO}_{2}$, placed in a Petri dish, and sliced into $1 \mathrm{~mm}$ thick sections with a sharp scalpel. The slices were shaken in $5 \mathrm{ml}$ PBS for $15 \mathrm{~min}$. The wash fluid was withdrawn and the process repeated. Wash fluids were pooled and adjusted $_{1} \boldsymbol{Q}_{\mathrm{i}} 1 \mathrm{Q}_{\mathrm{i}} \mathrm{ml}_{\mathrm{i}} \mathbf{P}_{\mathrm{r}}$ eliminary $\mathrm{y}_{4}$ experiments 
showed that this simple procedure recovered $95 \%$ of all spermatozoa in the cauda epididymidis and did not release excessive amounts of tissue debris into the wash fluids. The total number of spermatozoa per cauda epididymidis was estimated using a Quantimet 720 Image Analysing Computer which displays the image as it is counting. In a series of preliminary trials the sperm density estimated by the Quantimet did not differ significantly from haemocytometer estimates ( $>200$ estimates) but the standard deviation of the former was lower because more spermatozoa were counted for each sample (H. M. Dott \& G. C. Foster, unpublished). The Quantimet counted all the spermatozoa in $5 \mu \mathrm{l}$ whereas slightly more than 100 spermatozoa were counted in a haemocytometer, usually in a volume of $0.2 \mu \mathrm{l}$.

\section{Electrophoresis}

Nine other rabbits were surgically treated exactly as described above for Groups I, II and III ( 3 animals/group). Luminal contents were collected from the control and experimental cauda epididymidis by electrical stimulation (Jones \& Glover, 1973), centrifuged at $5000 \mathrm{~g}$ for $5 \mathrm{~min}$ in glass haematocrit tubes (Hawksby Ltd, Lancing, Sussex, U.K.) and the supernatant plasma was stored frozen at $-30^{\circ} \mathrm{C}$. A sample of blood plasma was also obtained from each rabbit at the time of death. Blood plasma and epididymal plasma were dialysed overnight against 50 $\mathrm{mM}$-Tris/glycine, $\mathrm{pH} 8.9$, containing $1 \%(\mathrm{w} / \mathrm{v})$ sodium dodecyl sulphate (SDS) and approximately $80 \mu \mathrm{g}$ protein loaded onto $7.5 \%$ cylindrical $(10 \mathrm{~cm} \times 0.7 \mathrm{~cm})$ polyacrylamide gels (Fairbanks, Steck \& Wallach, 1971). Electrophoresis buffer was $50 \mathrm{~mm}$-Tris/glycine, $\mathrm{pH}$ 8.9 , and the current was set at $3 \mathrm{~mA} /$ tuoe. Proteins were stained overnight in Coomassie Brilliant Blue in $40 \%(\mathrm{v} / \mathrm{v})$ methanol-7\% (v/v) acetic acid and de-stained in the same fixative without dye. Molecular weight marker proteins were obtained from Sigma Chemical Co. (London).

\section{Estimation of sperm motility}

Whole luminal contents were collected from the cauda epididymidis of normal rabbits by cannulation as described above and diluted 1:50 with PBS or epididymal plasma from normal, 3-week castrated, 5-week castrated or 5-week castrated rabbits receiving testosterone propionate. The mixture $(25 \mu \mathrm{l})$ was placed on a membrane slide (Miles \& Dott, 1979) at room temperature and the motility of spermatozoa, expressed as area change frequency (ACF), was monitored at 20-min intervals on a Quantimet 720 Analysing Computer (Dott \& Foster, 1979).

\section{Miscellaneous methods}

Protein was estimated by the procedure of Lowry, Rosebrough, Farr \& Randall (1951) and glucose by the hexokinase method (Bergmeyer, 1974).

\section{Results}

Table 1 shows the total number of spermatozoa in the control and experimental cauda epididymidis from Groups I, II and III. There was considerable variation between animals for the control sides with an overall mean of $1125 \pm 223 \times 10^{6}$. However, by 3 weeks after castration there was a decrease in total sperm numbers by $46 \%$ and by 5 weeks $>99 \%$ of spermatozoa had disappeared. A few sperm heads were present in 3 animals in Group II but they were too few in number to be counted accurately. In Group III animals there was no significant difference in total sperm numbers between control and experimental sides.

Granulomata were never observed on any of the experimental epididymides (Plate 1). Proximal to the ligature on the vas deferens the duct was always slightly swollen, particularly in 
Table 1. Total numbers $\left(\times 10^{-6}\right)$ of spermatozoa in the control and experimental cauda epididymidis of rabbits in Groups I, II and III (see text)

\begin{tabular}{|c|c|c|c|c|c|c|c|c|}
\hline \multirow[b]{2}{*}{ Rabbit } & \multicolumn{2}{|c|}{ Group I } & \multicolumn{3}{|c|}{ Group II } & \multicolumn{3}{|c|}{ Group III } \\
\hline & $\begin{array}{l}\text { Control } \\
\text { cauda }\end{array}$ & $\begin{array}{l}\text { Experimental } \\
\text { cauda }\end{array}$ & Rabbit & $\begin{array}{l}\text { Control } \\
\text { cauda }\end{array}$ & $\begin{array}{l}\text { Experimental } \\
\text { cauda }\end{array}$ & Rabbit & $\begin{array}{l}\text { Control } \\
\text { cauda }\end{array}$ & $\begin{array}{l}\text { Experimental } \\
\text { cauda }\end{array}$ \\
\hline 1 & 2770 & 1930 & 6 & 824 & $<0.001$ & 11 & 2040 & 2000 \\
\hline 2 & 267 & 265 & 7 & 538 & $<0.001$ & 12 & 3000 & 2800 \\
\hline 3 & 1301 & 513 & 8 & 741 & $<0.001$ & 13 & 270 & 340 \\
\hline 4 & 903 & 418 & 9 & 1370 & $<0.001$ & 14 & 560 & 890 \\
\hline 5 & 1330 & 384 & 10 & 552 & $<0.001$ & 15 & 420 & 540 \\
\hline Mean \pm s.e.m. & $1314 \pm 415$ & $702 \pm 309$ & & $805 \pm 151$ & $<0.001$ & & $1258 \pm 539$ & $1314 \pm 469$ \\
\hline
\end{tabular}

Group III animals. Distal to this ligature in Group III animals the lumen of the duct was narrow and no spermatozoa were found when it was irrigated with PBS. Some oedema was present in the experimental epididymides from Groups I and II but this was noticeably less in the animals in Group III.

Of the spermatozoa removed from each control cauda epididymidis, $>80 \%$ were vigorously motile with or without dilution in PBS and only $11 \pm 1.2 \%$ were eosinophilic. However, in the experimental epididymides of Group I $<5 \%$ of spermatozoa were motile and 91 and $61 \%$ were eosinophilic and tailless respectively. The few spermatozoa remaining in the cauda epididymidis in Group II animals were all eosinophilic and tailless. In Group III, however, motility ranged from 5 to $80 \%$ with a mean of $33 \pm 9.2 \%$ (s.e.m.). The proportion of eosinophilic and of tailless spermatozoa were $28 \pm 4 \cdot 1$ and $17 \pm 3 \cdot 8 \%$ respectively

Haematoxylin and eosin-stained smears of the luminal contents from each control cauda and from the experimental cauda epididymidis of animals in Group III revealed an abundance of intact spermatozoa with the occasional large nucleated cell, possibly a spermatid or spermatocyte. Smears of spermatozoa from the experimental cauda epididymidis in Groups I and II showed mostly detached sperm heads and tails. A small amount of other cellular material, not yet positively identified but possibly sloughed epithelial cells, was also present, and macrophages or leucocytes were seen occasionally.

Electrophoresis of the proteins from the epididymal plasma of control epididymides revealed a pattern different from that in blood plasma: it was characterized by 4 major polypeptides,

\section{PLATE 1}

Epididymides from 5-week castrated (Group II) and 5-week castrated + testosterone-treated (Group III) rabbits. FP $=$ fat pad. Arrows indicate position of ligatures on the corpus epididymidis and vas deferens.

Fig. 1. Epididymides of Rabbit 7 (Group II) showing the control epididymis (left) with the cauda epididymidis and vas deferens engorged with spermatozoa, and the experimental epididymis (right) which contains watery fluid devoid of spermatozoa.

Fig. 2. Epididymides of Rabbit 14 (Group III) demonstrating the similarity of the experimental epididymis (right) to the control epididymis (left) with respect to sperm content.

\section{PLATE 2}

Electrophoresis on $7.5 \%$ polyacrylamide gels containing sodium dodecyl sulphate of blood serum and cauda epididymal plasma proteins from rabbits in Groups I (Fig. 3), II (Fig. 4 and III (Fig. 5). In each figure the patterns are those for (a) blood serum; (b) plasma from the control epididymis; and (c) plasma from the experimental epididymis. 
PI.A]1: I
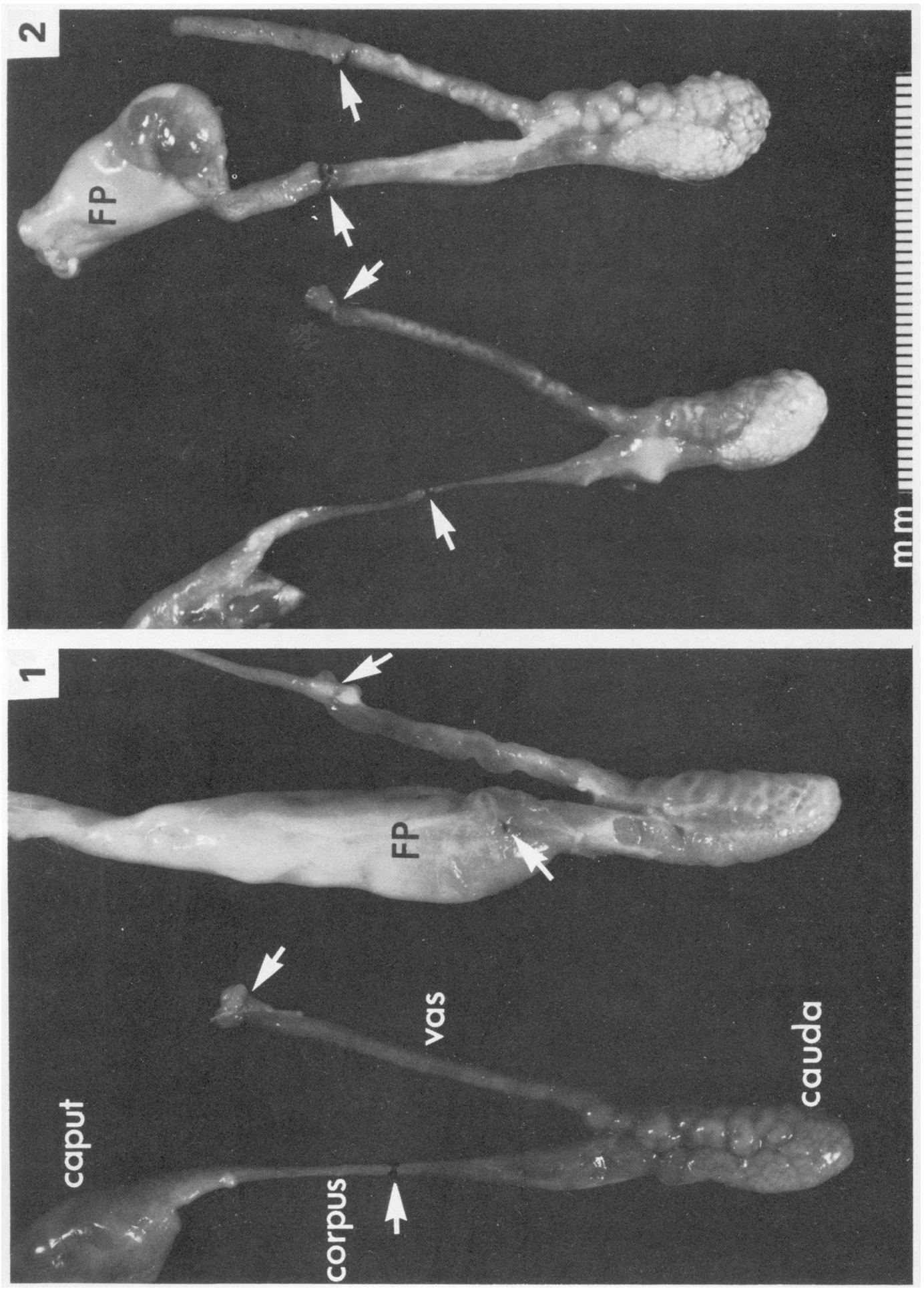


\section{PLATE 2}

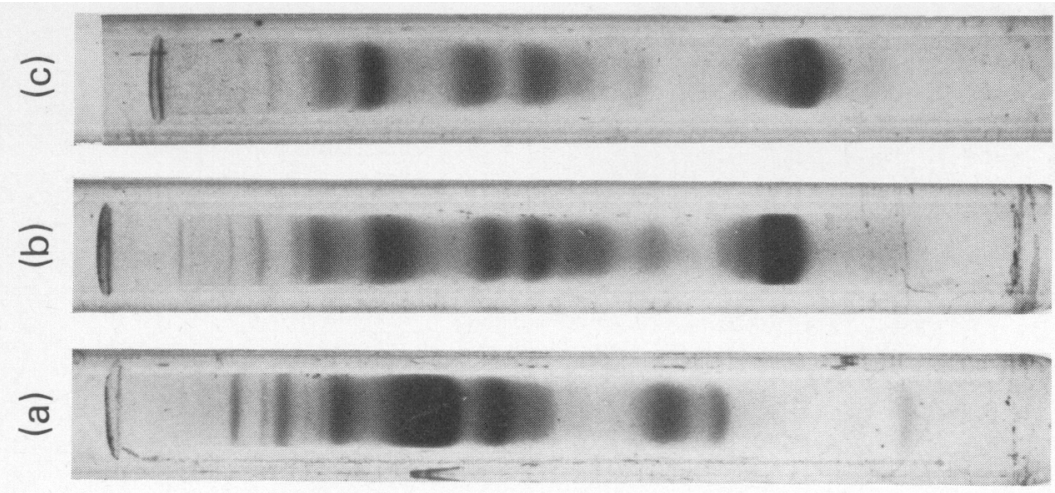

เด
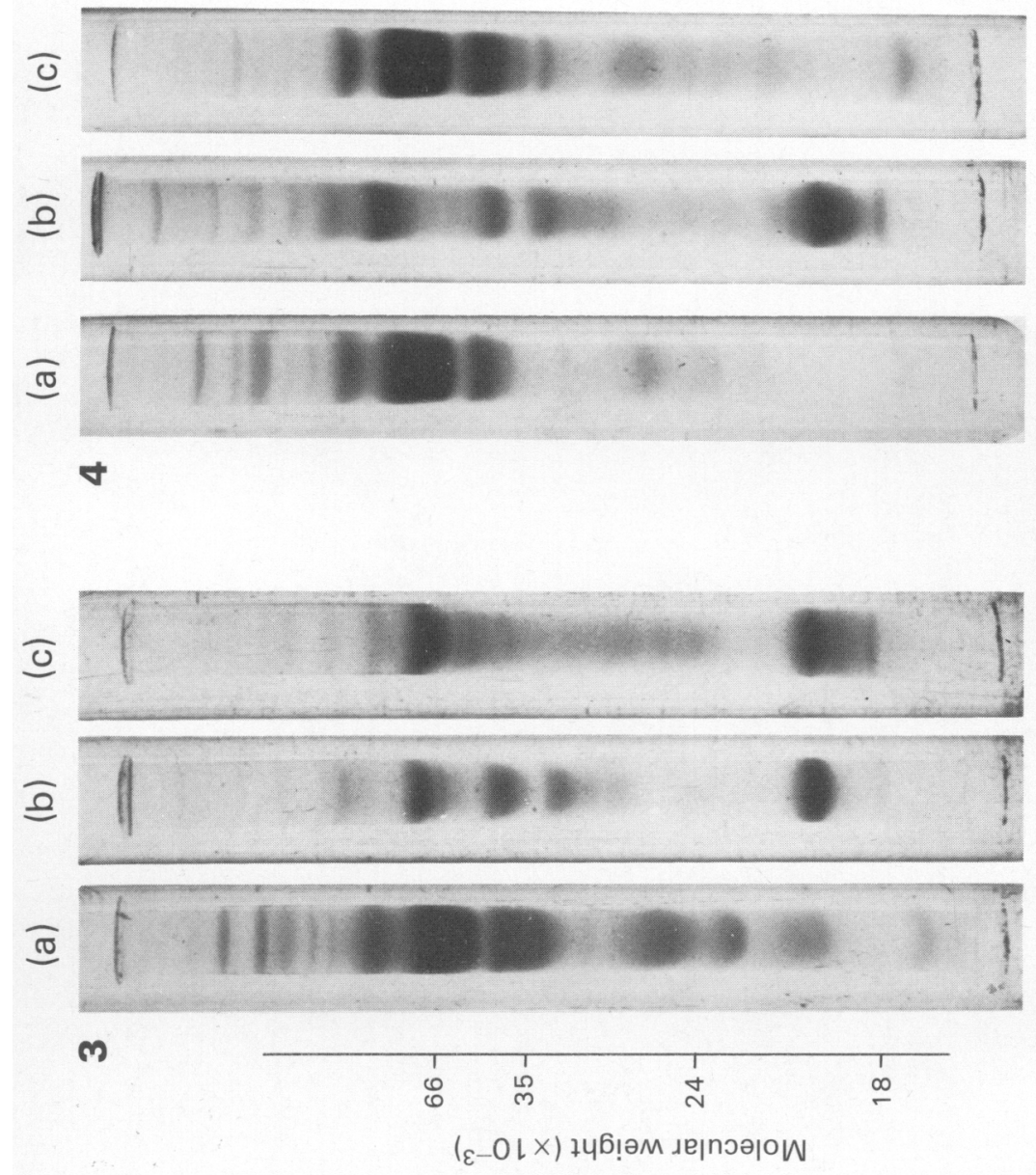
with apparent molecular weights of $20000,30000,35000$ and 66000 (Plate 2). By 3 weeks after castration (Group I) the polypeptides of molecular weights 30000 and 35000 became indistinct and there was a characteristic diffuse pattern of smaller peptides. In the experimental epididymides of Group II the 20000 molecular weight protein had disappeared altogether and the protein composition of the epididymal plasma was almost identical to that of blood plasma. There were no apparent differences in Group III rabbits between the control and experimental epididymides.

Since these results, in combination with our previous work (Jones \& Glover, 1975), demonstrated considerable changes in the composition of the cauda epididymal plasma after castration, it was of interest to examine the effects of this altered milieu on sperm motility (Text-fig. 1). Spermatozoa collected from the cauda epididymidis of normal rabbits and diluted 1:50 with normal epididymal plasma gave a low but constant ACF for at least 60 min at $30^{\circ} \mathrm{C}$. Although $>85 \%$ of the spermatozoa were motile, their rate of forward progression was slow and so a low ACF index was registered. (In fact, this motility persisted for several hours and a few spermatozoa were still motile after storage for several days at room temperature.) Dilution in PBS, however, stimulated vigorous forward motility but this declined rapidly to barely detectable levels within $20 \mathrm{~min}$. Epididymal plasma from 3-week and 5-week castrated rabbits also stimulated vigorous motility and although this declined after $40 \mathrm{~min}$, the rate of decrease was less than in samples diluted in PBS. The fact that epididymal plasma from castrated rabbits was similar to blood plasma, in terms of electrolyte and protein composition, suggested that traces of blood glucose may also be present and that this might account for the slightly prolonged motility of spermatozoa. Glucose could not be detected in the plasma from the cauda epididymidis of normal or castrated animals treated with testosterone, but levels of 0.87 and $0.26 \mathrm{~mm}$-glucose were found in epididymal plasma from 3- and 5-week castrates respectively.

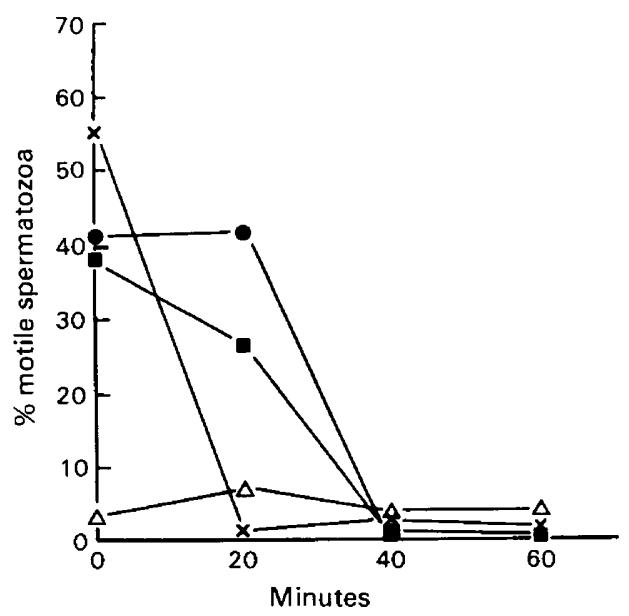

Text-fig. 1. Motility at $30^{\circ} \mathrm{C}$ of spermatozoa from the rabbit cauda epididymidis diluted 1:50 in PBS $(x)$, epididymal plasma from normal animals $(\triangle)$, from 3-week castrated animals $(\bullet)$, and from 5-week castrated animals ( $\square$ ).

\section{Discussion}

These results confirm our earlier observations (Jones \& Glover, 1975) that $>95 \%$ of spermatozoa disappear from the ligated cauda epididymidis of the rabbit within 5 weeks of removing the testes. This disappearance of spermatozoa is not associated with the formation $_{4}$ 
of granulomata or phagocytosis by the epididymal epithelium, but appears to take place within the lumen of the duct. After castration the protein composition of the epididymal luminal fluid changes considerably to give a pattern on SDS polyacrylamide gels almost identical to that in blood serum, and the duration of motility of spermatozoa diluted in this epididymal plasma is severely reduced.

Temple-Smith \& Bedford (1978) observed in hamsters and rabbits that ligation of the cauda epididymidis elicited the formation of granulomata either on the vas deferens or in the cauda itself. Whilst we agreee that granulomata are easily induced in hamsters and rats this is not the case in rabbits, in which the vas deferens and cauda epididymidis are very muscular and distensible and can accommodate considerable back-pressure without rupturing. This is shown most clearly after vasectomy when the vas deferens and cauda epididymidis become so engorged with spermatozoa that after 6 months they are larger than the testis (Jones, 1974; Bedford, 1976). Other investigators have also performed ligation experiments on the rabbit epididymis but none has reported granulomata (Gaddum \& Glover, 1965; Paufler \& Foote, 1969). In our experience they are a rare occurrence and can usually be attributed to poor surgical technique. Perhaps the most convincing evidence that the present results were not due to faulty surgery is the finding that in castrated animals given testosterone (Group III) granulomata were not present and there was no significant reduction in sperm numbers in the cauda. Whether or not granulomata are formed it would appear that removal of dead spermatozoa is dependent upon their retention within the lumen of the epididymis because Temple-Smith \& Bedford (1978) did not find a reduction in sperm numbers in granulomata.

At present we can only speculate on the mechanism of sperm disposal after castration. Like other investigators we found no evidence for phagocytosis of spermatozoa by the epithelium or by invading macrophages, and we are forced to conclude that they undergo a form of lysis within the lumen of the duct. This disposal of dead cells is not unusual or unique to the epididymis as the involution of many hormone-dependent tissues is accompanied by removal of effete cells. For example, regression of the sheep corpus luteum involves the reduction of approximately $0.5 \mathrm{~g}$ tissue to $\sim 50 \mathrm{mg}$ within 6 days (R. M. Moor, personal communication). It is thought that this destruction of cells is due to autophagy mediated by lysosomal enzymes (Dingle, Hay \& Moor, 1968). We suggest that in the normal animal lysosomal enzymes in the epididymal secretion exist in a zymogen form, but that after castration the rapid changes within the lumen of the duct (Jones \& Glover, 1975) induce activation of proteolytic enzymes leading to decapitation of spermatozoa and eventually to dispersion of nucleoprotein. In agreement with the results of Marushige \& Marushige (1975, 1978), but in contrast to those of Calvin \& Bedford (1971) and Young (1979), we have found that sulphydryl compounds alone, e.g. $\beta$-mercaptoethanol at $\mathrm{pH} 8.0$, decondense sperm nuclei (M. R. F. Mennella \& R. Jones, unpublished observations). It remains to be shown if a thiol-reducing capacity is present in cauda epididymal plasma after castration.

The composition of the plasma of the cauda epididymidis in the normal rabbit seems to be androgen-dependent, since testosterone is required for the epididymis to transfer selectively certain proteins from blood, or to stimulate the synthesis and secretion of epididymal-specific proteins. It is likely that this barrier is maintained at the epididymal epithelium because castration is known to cause rapid involution of the cells lining the duct (Jones, Hamilton \& Fawcett, 1979; Moore \& Bedford, 1979). The appearance of small peptides in the epididymal plasma from 3-week castrated animals may be due to degradation of larger plasma proteins or to their release from degenerating spermatozoa. At present, the latter seems the most likely in view of the fact that all spermatozoa are tailless at this time.

We thank Miss G. Elliott for technical assistance. 


\section{References}

Amann, R.P. \& Almquist, J.O. (1962) Reproductive capacity of dairy bulls. VI. Effect of unilateral vasectomy and ejaculation frequency on sperm reserves; aspects of epididymal physiology. $J$. Reprod. Fert. 3, 260-268.

Amann, R.P., Kavanaugh, J.F., Griel, L.C. \& Voglmayr, J.K. (1974) Sperm production of Holstein bulls determined from testicular spermatid reserves, after cannulation of rete testis or vas deferens, and daily ejaculation. J. Dairy Sci. 57, 93-99.

Bedford, J.M. (1975) Maturation, transport and fate of spermatozoa in the epididymis, In Handbook of Physiology, Vol. V, pp. 303-317. Eds R. O. Greep \& D. W. Hamilton. Am. Physiol. Soc., Washington D.C.

Bedford, J.M. (1976) Adaptations of the male reproductive tract and the fate of spermatozoa following vasectomy in the rabbit, rhesus monkey, hamster and rat. Biol. Reprod. 14, 118-142.

Bergmeyr, H.U. (1974) Methods of Enzymatic Analysis. Academic Press, New York.

Calvin, H.I. \& Bedford, J.M. (1971) Formation of disulphide bonds in the nucleus and accessory structures of mammalian spermatozoa during maturation in the epididymis. J. Reprod. Fert., Suppl. $13,65-75$.

Cooper, T.G. \& Hamilton, D.W. (1977) Phagocytosis of spermatozoa in the terminal region and gland of the vas deferens of the rat. Am. J. Anat. 150, 247-268.

Crabo, B., Gustafsson, B., Nicander, L. \& Rao, A.R. (1971) Subnormal testicular function in a bull concealed by phagocytosis of abnormal spermatozoa in the efferent ductules. J. Reprod. Fert. 26, 393396.

Dingle, J.T., Hay, M.F. \& Moor, R.M. (1968) Lysosomal function in the corpus luteum of the sheep. J. Endocr. 40, 325-336.

Dott, H.M. \& Foster, G.C. (1975) A technique for studying the morphology of mammalian spermatozoa which are eosinophilic in a differential 'live/dead' stain. J. Reprod. Fert. 29, 443-445.

Dott, H.M. \& Foster, G.C.A. (1979) The estimation of sperm motility in semen, on a membrane slide, by measuring the area change frequency with an image analysing computer. J. Reprod. Fert. 55, 161-166.

Fairbanks, G., Steck, T.L. \& Wallach, D.F.H. (1971) Electrophoretic analysis of the major polypeptides of the human erythrocyte membrane. Biochemistry, N.Y. 10, 2606 2617.

Gaddum, P. \& Glover, T.D. (1965) Some reactions of rabbit spermatozoa to ligation of the epididymis. $J$. Reprod. Fert. 9, 119-130.

Hoffer, P.A., Hamilton, D.W. \& Fawcett, D.W. (1975) Phagocytosis of spermatozoa by the epithelial cells of the ductuli efferentes after epididymal destruction in the rat. J. Reprod. Fert. 44, 1-9.

Jones, R. (1974) Epidydmal function in the vasectomized rabbit. J. Reprod. Fert. 36, 199-202.

Jones, R. \& Glover, T.D. (1973) The effects of castration on the composition of rabbit epididymal plasma. $J$. Reprod. Fert. 34, 405-4141.
Jones, R. \& Glover, T.D. (1975) Interrelationships between spermatozoa, the epididymis and epididymal plasma. In The Biology of the Male Gamete, pp. 367-384. Eds J. G. Duckett \& P. A. Racey. Academic Press, London.

Jones, R., Hamilton, D.W. \& Fawcett, D.W. (1979) Some effects of testosterone, $5 \alpha$-dihydrotestosterone, and $5 \alpha$-androstene- $3 \alpha, 17 \beta$-diol on the morphology of the rabbit epididymis and prostate. J. Ultrastruct. Res. 67, 194-208.

Koefoed-Johnson, H.H. (1964) Sperm production in bulls. The excretion of sperm in the urine at different ejaculation frequencies. Ann. Rep. vet. Agric. Coll. Sterility Inst., Copenhagen, pp. 23-27.

Lincoln, G.A. (1974) Reproduction and 'March Madness' in the brown hare, Lepus europaeus. $J$. Zool., Lond. 174, 1-14.

Lowry, O.H., Rosebrough, N.J., Farr, A.L. \& Randall, R.J. (1951) Protein measurement with the Folin phenol reagent. J. biol. Chem. 193, 265-275.

Lubicz-Nawrocki, C.M. (1974) Effects of castration and testosterone replacement on the number of spermatozoa in the cauda epididymidis of hamsters. J. Reprod. Fert. 39, 97-100.

Mann, T. (1964) The Biochemistry of Semen and of the Male Reproductive Tract. Methuen, London.

Marushige, Y. \& Marushige, K. (1975) Enzymatic unpacking of bull sperm chromatin. Biochim. Biophys. Acta 403, 180-191.

Marushige, Y. \& Marushige, K. (1978) Dispersion of mammalian sperm chromatin during fertilization: an in vitro study. Biochim. Biophys. Acta 519, 1-22.

Mennella, M.R.F. \& Jones, R. (1977) The activity of some nucleolytic enzymes in semen and in the secretions of the male reproductive tract. Andrologia 9, 1, 15-21.

Miles, P. \& Dott, H.M. (1979) The construction of a membrane slide support for the observation of living cells. J. Microscopy 115, 111-112.

Millar, R.P. (1972) Degradation of spermatozoa in the epididymis of a seasonal breeding mammal, the rock hyrax, Porcania capensis, J. Reprod. Fert. 30, 447-450.

Moore, H.M.D. \& Bedford, J.M. (1979) Short-term effects of androgen withdrawal on the structure of different epithelial cells in the rat epididymis. Anat. Rec. 193, 293-312.

Paufer, S.K. \& Foote, R.H. (1969) Sperm retention and resorption in sexually active rabbits with epididymal ligatures. Proc. Soc. Biol. Med. 131, 1179-1183.

Phadke, A.M. (1964) Fate of spermatozoa in case of obstructive azoospermia and after ligation of vas deferens in man. J. Reprod. Fert. 7, 1-12.

Roussel, J.D., Stallcup, O.T. \& Austin, C.R. (1967) Selective phagocytosis of spermatozoa in the epididymis of bulls, rabbits and monkeys. Fert. Steril. 18, 509-516.

Sinowatz, F., Wrobel, K.-H., Sinowatz, S. \& Kugler, P. (1979) Ultrastructural evidence for phagocytosis of spermatozoa in the bovine rete testis and testicular straight tubules. J. Reprod. Fert. 57, 1-4. 
Temple-Smith, P.D. \& Bedford, J.M. (1978) Fate of spermatozoa in the male. II. Absence of a specific sperm disposal mechanism in the androgen-deficient hamster and rabbit. Biol. Reprod. 18, 791-798.

Tingari, M.D. \& Lake, P.E. (1972) Ultrastructural evidence for resorption of spermatozoa and testicular fluid in the excurrent ducts of the testis of the domestic fowl, Gallus domesticus. J. Reprod. Fert. 31, 373-381.
Waldschmidt, M., Karg, H. \&inzler, M. (1964) Vorkemmen von Desoxyribonublease in mannlichen Geschlectssekneten beim Rind. Naturwissenschaften 51, 364-366.

Young, RJ. (1979) Rabbit sperm chromatin is decondensed by a thiol-induced proteolytic activity not endogenous to its nucleus. Biol. Reprod. 20, 10011004.

Received 12 November 1979 